\title{
(Medieskabt) Ekspertise i Medierne
}

Artiklen indeholder en analyse af nogle af de sociale dynamikker, der ligger bag optrædener som ekspertkilde i medierne. De empiriske studier, som artiklen er baseret på, viser, at journalister søger personer, der har "autoritet", og som derfor kan udtale sig med "vægt". På denne baggrund defineres fænomenet ekspertise som symbolsk kapital i Pierre Bourdieus forståelse, det vil sige som kapital (videnskabelig, kulturel, intellektuel etc.), der gen- og anerkendes som "kompetence“. Disse overvejelser perspektiveres gennem en diskussion af opkomsten af nye ekspertprofessioner samt afslutningsvist gennem en diskussion af mediernes rolle som kapitalskabere. 

eksperter for givet, men hvem er egentlig eksperter? Hvis en journalist til eksempel vil skrive en historie omkring børn og unges kostvaner, vil den bedste ekspert så være en skolelærer, der omgås unge hele dagen, en markedsanalytiker, der laver analyser for fødevareindustrien eller en universitetsforsker, der forsker i kostvaner? Spørgsmålet er ikke blevet mindre kompliceret $\mathrm{i}$ takt med, at viden - som eksemplet antyder - $\mathrm{i}$ dag produceres $\mathrm{i}$ en række forskellige institutioner. Valget står altså ikke længere mellem praktisk viden og teoretisk/videnskabelig viden, men også mellem en lang række forskellige typer teoretisk og måske endda forsknings- (eller „,analyse-“) baseret viden.

Denne artikel forsøger at argumentere for to postulater: For det første, at det, der udgør ekspertise og dermed kvalificerer bestemte personer til at fungere som ekspertkilder i nyhedshistorier, i lige så grad handler om at have en bestemt status og en bestemt autoritet, som det handler om at have en bestemt type viden om det relevante emne. For det andet, at der i takt med samfundsudviklingen i de seneste 30-40 år er sket en pluralisering af relevante ekspertkilder (Rich 2001: 584), og at mediernes selv er blevet vigtige aktører i spillet om, hvem der er eksperter. Dette skyldes, at medieoptrædener i sig selv skaber status og autoritet, hvorved journalistik som profession har vundet anseelse og status. Derfor er medieoptrædener autoritetsskabende for eksperter, og journalister kan også selv optræde som eksperter. Artiklens endelige argument er med andre ord, at det moderne vidensamfund har åbnet op for en ny konkurrencetilstand om, hvad der udgør ekspertise, og at denne konkurrence foregår i og gennem massemedierne. Dette angår naturligvis også den klassiske vidensinstitution - universitetet - der i højere grad skal konkurrere med andre om den autoritet og status, som universitetsforskning (og forskere) hidtil har nydt i offentligheden.

\section{Baggrund}

Før man begynder at analysere og diskutere journalisters brug af ekspertkilder, er det nyttigt at skrive sig to - tilsyneladende hinanden modsigende - ting bag øret. Vores moderne samfund er for det første på mange måder et vidensafhængigt samfund. Dette betyder, at viden og ekspertise ikke kun udvikles eller findes i akademiske elfenbenstårne: Viden er konstant i spil, i økonomien, i politik, i offentligheden og i det enkelte menneskes private liv. Der er mange årsager til dette, ligesom dette faktum manifesterer sig på mange måder. Blandt dem er der tre, jeg vil nævne her:

1) Megen produktion og økonomisk aktivitet er vidensbaseret, hvilket gør, at viden og ekspertise udvikles og bruges i mange forskellige institutioner og virksomheder og ikke kun i universiteter.

2) Moderne (uforståelig) teknologi og ikke mindst de medfølgende ri- 


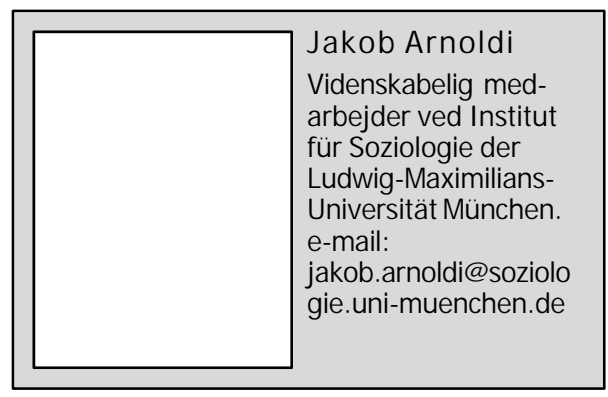

sici gør, at ekspertviden bliver vigtigere i politik og den politiske offentlighed. Og endeligt

3) er store områder af det moderne menneskes liv i dag frigjort fra traditioner, hvilket skaber mange muligheder men også et behov for ekspertviden, der kan give det bedst mulige grundlag for at håndtere de mange muligheder, som tabet af traditioner skaber.

Det andet faktum, man bør skrive sig bag øret, er, at mennesker - lige meget i hvilken tid og hvilken kultur de lever i - har et behov for bestemte autoritative fortolkninger eller beskrivelser af deres samfund og -tid. Hvilke typer viden (med „viden" forstås her forskellige symbolske systemer der samlet danner en "verdensanskuelse“ - religion er således også et videnssystem), der har den største legitimitet og relevans og hvilke mennesker, der anses for de bedst kvalificerede til at komme med sådanne fortolkninger og beskrivelser, er dog historisk varierende. Men hvad enten vi har at gøre med en shaman i et stammesamfund, en præst, en intellektuel eller en ekspert, så indtog eller indtager disse personer en privilegeret position i samfundet eller offentligheden - blandt andet $i$ kraft af deres profession og den viden og andre kompetencer, som deres profession giver dem.

Disse to konstateringer udgør den kontekst eller den forforståelse, som alle refleksioner over eksperter i offentligheden må foregå på baggrund af. Man bør således huske, at fænomenet ekspertkilder i massemedierne både er en ny og en gammel historie. Eksperter begynder at forekomme i større antal i nyhedshistorier samtidig med opkomsten af objektivitetskriteriet i moderne amerikansk journalistik (begyndende i 1920'erne - objektivitetskravet har siden bredt sig også til Danmark) og brugen af ekspertkilder har - i Danmark og i USA været stigende de sidste årtier (Albæk, Christiansen \& Togeby 2002; Steele 1995: 800). Men samtidig er dette blot en variant af en gammel historie, nemlig historien om personer, hvis udsagn nyder en særlig autoritet og har en særlig status i offentligheden. 


\section{Hvem er eksperter?}

Disse to forforståelser af fænomenet eksperter i nyhedsmedier peger på nogle ubesvarede problematikker. Det spørgsmål, denne artikel vil beskæftige sig med, handler om selve definitionen af ekspertise. Hvis vi antager, at de personer, vi betegner som „eksperter, " blot er udtryk for den almengyldige regel, at visse personer og visse typer viden altid, i et hvilket som helst samfund, har en særlig status og autoritet, bliver det samtidig klart, at eksperter ikke kan defineres gennem deres profession eller uddannelse alene og ej heller gennem nogle iboende karaktertræk ved den viden eller de erfaringer, som eksperterne besidder (se Collins \& Evans 2002 for et sådant argument). Jeg indtager med andre ord en anti-essentialistisk tilgang til fænomenet ekspertise (se også note 1).

Når man kigger nærmere på nyhedsmediernes brug af ekspertkilder (tabel 1) forstærkes dette indtryk: Langt fra alle de benyttede "eksperter" er universitetsansatte forskere. Der er mange andre professionsgrupper repræsenteret, heriblandt en del journalister og redaktører, og man kan således ikke blot definere eksperter som videnskabsfolk eller universitetsansatte.

Tabel 1: ekspertkilder i tre danske aviser opgjort efter erhverv $(n=138)^{1}$

\begin{tabular}{lrc}
\hline Læger (privat og offentligt ansatte) & 19 \\
\hline $\begin{array}{l}\text { Forskere (universitetsansatte) } \\
\quad \text { Heraf naturfaglige }\end{array} \quad 16$ & \\
$\quad \begin{array}{l}\text { Samfundsvidenskabelige } \\
\text { Humanvidenskabelige } \\
\text { Ikke angivne }\end{array}$ & 31 & \\
\hline $\begin{array}{l}\text { Privatansatte/selvstændige } \\
\quad \text { Heraf bankansatte }\end{array}$ & 24 & \\
\hline $\begin{array}{l}\text { Bevægelser, foreninger, selskaber } \\
\text { eller interesseorganisationer }\end{array}$ & 18 \\
\hline Råd, nævn og styrelser & 51 \\
\hline Andre kommunalt, amtsligt eller statsligt ansatte & 12 \\
\hline Andre & 13 \\
\hline I alt & 210 \\
\hline
\end{tabular}


Tabel 2: Ekspertkilder i DR1s TV-avisen og TV2's Nyhederne opgjort efter erhverv ( $n=64)$.

\begin{tabular}{|c|c|}
\hline Læger (privat og offentligt ansatte) & 11 \\
\hline Forskere (universitetsansatte) & 15 \\
\hline Heraf naturfaglige & 1 \\
\hline Samfundsvidenskabelige & 7 \\
\hline Humanvidenskabelige & 2 \\
\hline Ikke angivne & 5 \\
\hline $\begin{array}{l}\text { Privatansatte/selvstændige } \\
\text { Heraf bankansatte }\end{array}$ & 7 \\
\hline $\begin{array}{l}\text { Bevægelser, foreninger, selskaber } \\
\text { eller interesseorganisationer }\end{array}$ & 2 \\
\hline Råd, nævn, direktorater og styrelser & 5 \\
\hline Andre kommunalt, amtsligt eller statsligt ansatte & 8 \\
\hline Journalister & 6 \\
\hline Andre & 17 \\
\hline I alt & 71 \\
\hline
\end{tabular}

Lad os derfor for et øjeblik sætte spørgsmålet om, hvem eksperter er, til side og i stedet fokusere på, hvilke funktioner ekspertudsagn har i nyhedshistorier. Vi kigger dermed ikke på, hvad eksperter gør - de udtaler sig naturligvis om forskellige forhold - men på den rolle, som deres udsagn spiller i nyhedstekster. Min analyse af materialet, der også er gengivet i tabel 1 og 2, viser (se også Arnoldi 2005), at ekspertudsagn,

1) underbygger nyhedshistoriernes vinkler (og ofte den kritik som historierne rummer),

2) bruges til at perspektivere og forklare betydningen af de hændelser, der er nyhedshistoriernes hovedemne.

I det førstnævnte tilfælde benyttes eksperten til at understøtte artiklen eller sagt på en anden måde, så bruger journalisterne eksperter til at finde „fodfæste“ („footing" - se Potter 1996: 142-145) for deres artikler. En typisk måde, 
hvorpå dette foregår, er artikler, der omhandler bestemte kritisable „sager," hvor eksperter er belæg for, at sagen virkeligt er kritisabel. Den anden nævnte rolle, som ekspertkilder typisk spiller i nyhedshistorier, er at vurdere betydningen af hændelser eller at forklare dem. Dette involverer perspektiveringer, forklaringer af årsager og af mulige fremtidige konsekvenser. Denne ekspertrolle rummer faktisk et paradoks (Arnoldi 2005; Nowotny 2000b): En ekspert er egentlig en person, der ved meget om et lille og afgrænset område. Men sådanne perspektiveringer og vurderinger af betydninger involverer kontekst og bestemte hændelsers mulige konsekvenser for en lang række andre ting. Ekspertkilden kan derfor ikke holde sig inden for sit eget ekspertisefelt. Hendes opgave er faktisk den modsatte: at forklare betydningen og konsekvenserne af hændelser, der relaterer sig til hendes ekspertisefelt, for en lang række andre områder, der ikke nødvendigvis ligger sig inden for hendes ekspertisefelt. Også i dette andet tilfælde synes ekspertens autoritet at være vigtig. Autoritet er vigtig, fordi autoritet hænger sammen med tillid. Ekspertkilder benyttes i denne forbindelse til at skabe en sammenhæn og en dybere betydning af de hændelser, der dækkes i nyhederne, og sådanne analyser af betydningen eller sammenhængen kan kun fungere, hvis de virker tillidsvækkende og overbevisende

Men hvori består denne autoritet? Interviews med journalister viser, at de opererer med nogle relativt brede kriterier for hvad, der gør bestemte personer til eksperter. Men selv om definitionerne er brede, er der nogle basale karaktertræk, som det følgende udsagn på mange måder demonstrerer:

Titler er jo ikke i sig selv vigtige for os, men det er jo klart, at eksperter for os er folk, som vi dels vurderer ved noget om området, og som dels typisk sidder et sted, der giver dem den status det kræver, at de kan udtale sig med en vis vægt. Og i sagens natur vil det jo næsten altid være akademikere der sidder i den slags stillinger, ikke. Men det er jo ikke sådan, altså vi checker jo aldrig deres uddannelsesbaggrund [...] det er jo ikke noget kriterium i sig selv, ville jeg tro. I virkelighedens verden vil det vise sig at det altovervejende er akademikere (Politisk redaktør, dansk landsdækkende dagblad).

Eksperter er altså i denne definition dels nogen, der „,ved noget om området,“ dels personer, der har „,status, “ og dermed kan udtale sig med „,vægt.“ På den ene side er indehavelsen af en titel ikke noget nagelfast kriterium. Men på den anden side forekommer det klart, at en akademisk titel, og det at have en bestemt profession, hjælper til at forlene eksperten med den status, som er nødvendig for at kunne fungere som ekspert.

Hvem bestemmer, hvilke professioner der har den fornødne status og dermed autoritet? Det er naturligvis journalisterne og redaktørerne, der udvælger 
eksperterne, så det er i sagens natur dem, der i første omgang foretager denne vurdering. Men omvendt kan denne udvælgelse af eksperter kun fungere, hvis modtagerne af nyhedshistorierne til en vis grad deler journalisternes forestillinger om, hvem der har denne status. Afsendere (journalister) og modtagere (publikum) skal altså til en vis grad begge gen- og anerkende de udvalgte eksperters kompetencer.

Dette indikerer, at ekspertise hviler på social gensidighed: ekspert er man, når man anerkendes af andre som ekspert. Denne gen- og anerkendelse hviler på en række komplekse forforståelser eller konventioner, som i vid udstrækning deles af journalister og deres publikum, og som i øvrigt til stadighed reproduceres gennem journalisternes brug af ekspertkilder: Journalister vælger eksperter ud fra nogle brede konventioner om, hvad gyldig og autoritativ viden er - hvorved disse konventioner reproduceres. Disse socialt delte konventioner rummer et værdihierarki, der afgør, hvad der er gyldig "ekspertviden“ og hvilke faggrupper, der kan fungere som eksperter. I vores samfund, hvor teoretisk viden har så høj en status, kan det ikke undre, at det som hovedregel er folk med videregående akademiske uddannelser, der fungerer som eksperter i medierne. Personer med praktisk erfaring og med kortere uddannelser figurerer i langt mindre grad. Men omvendt er hierarkierne stadig „til forhandling" og dermed også historisk foranderlige.

\section{Autoritet, status og kapital}

Foreløbig har jeg berørt nogle generelle karaktertræk ved eksperter og ekspertise: Jeg har nævnt, at eksperter er personer, som - $\mathrm{i}$ kraft af deres viden - besidder en autoritet, der giver deres udsagn en særlig vægt, en vægt som journalister genkender som ekspertise. Denne autoritet hviler, har jeg videre foreslået, på nogle sociale konventioner om, hvilke typer viden og hvilke professionsgrupper der kan siges at udgøre ekspertise og eksperter. For at give disse hypoteser mere kongruens vil jeg nu inddrage Pierre Bourdieus begreb kapital og senere hans begreb felt.

Bourdieus idé om kapital kan kort formuleres således: Med udgangspunkt i Karl Marx mener Bourdieu, at kapital er en ressource, der kan besiddes, som afgør den enkelte persons position i samfundet, dannes gennem forskellige former for ",arbejde“ og akkumuleres gennem „investeringer" (Bourdieu 1986). Selv om økonomisk kapital naturligvis er en af de vigtigste kapitalformer, så findes der også en række andre former for kapital, der kan sikre personer en høj position i samfundet. Den kapitalform, som Bourdieu - sammen med økonomisk kapital - anser for at være den vigtigste, er kulturel kapital (Bourdieu 1986, 1989, 1997). Og det er også denne kapitalform, der - sammen med symbolsk kapital - vil blive fokuseret på i denne artikel.

Kulturel kapital kan i besiddes i forskellige former. I den form Bourdieu kalder den objektiverede, består den kulturelle kapital i besiddelsen af bøger, kunstværker og andre æstetiske og kulturelle artefakter. I den kropsliggjorte 
form består kapitalen i habitus, dvs. bestemte prædisponeringer for handling (Bourdieu 1977, 1984, 1990). Og endeligt er der den institutionaliserede form, der består af uddannelse og andre formelle kvalifikationer (Bourdieu 1986: 243).

Kulturel kapital i den institutionaliserede form - uddannelse - er således blandt de ting, der sikrer eksperter deres status og dermed autoritet. Men Bourdieu hævder ikke, at det er den viden, der er tilegnet gennem uddannelse, der gør en person til ekspert - snarere tværtimod. Bourdieus kapitalbegreb er interessant, fordi det forudsætter, at der ikke er noget essentielt, der udgør kapital (Bourdieu 1997: 19). Kapitals værdi er ikke en indre værdi, men en værdi der dannes ved, at alle anerkender noget som værdifuldt (hvad enten det så er guld, titler eller eksamensbeviser). De kompetencer, som eksperter besidder, er således kun værdifulde eller statusgivende, fordi de gen- og anerkendes af de fleste (Bourdieu 1993). Sat på spidsen er det ikke eksperters viden, der gør dem til eksperter, men den status som eksperter nyder i kraft af andres anerkendelse af dem. Bourdieu taler om, at netop især kulturel kapital har en tendens til at blive bredt anerkendt. Derved bliver det til symbolsk kapital - andre anerkender kapitalens symbolske værdi (Bourdieu 1989: 17; 1991: 72). I den måske mest skarpe formulering Bourdieu kommer med, siger han, at kulturel kapital fejlagtigt ikke bliver opfattet som kapital men i stedet opfattet som legitim kompetence (,,unrecognized as capital and recognized as legitimate competence, as authority existing as effect of (mis) recognition“ Bourdieu 1986: 245).

Man kan naturligvis indvende, at dette skarpe skel mellem på den ene side reelle kompetencer eller reel viden og på den anden side den status og autoritet, som bestemte titler og professioner giver, er misvisende og fejlagtig, fordi det, eksperter leverer til nyhedshistorier, virkelig er viden. Men jeg mener, at der er grund til at tage dette skel meget alvorligt af en række årsager. Det er faktisk langt fra sådan, at ekspertkilderne i nyhedshistorier decideret leverer viden. For det første forekommer det ganske ofte, at journalisterne allerede har indsamlet den relevante viden eller information. Men dels forhindrer objektivitetskriteriet dem i at tilskrive denne viden til dem selv - de skal have kilder - dels forsøger de at øge deres historiers troværdighed ved at referere eller citere autoritative ekspertkilder. I disse tilfælde leverer eksperten altså ikke afgørende ny viden, men blot en titel og dermed autoritet og troværdighed. Denne arbejdsmetode betyder i øvrigt også, at journalister ofte anklages for at have "vinklet historien" allerede før, de kontakter deres ekspertkilder (Wien 2001).

For det andet er ekspertkilder ofte transgressive (Nowotny 2000b) i den forstand, jeg beskrev ovenfor: Ekspertkilder bliver bedt om at vurdere, hvilke betydninger, hændelser, der relaterer sig til deres fagområde, har for en vifte af andre ting, der ikke nødvendigvis falder inden for deres ekspertisefelt. I disse tilfælde er eksperterne i deres kommentarer nødsaget til at bevæge sig ud over 
deres ekspertisefelt. I det hele taget synes det meget ofte at være således, at eksperter - f.eks. universitetsforskere - udtaler sig om ting, der næsten - men ikke helt - falder inden for deres forskningsfelt. Dette leder til den samme konklusion som før. Det, der fra journalistside efterspørges, er ikke kun viden, men også nogle symbolske former for autoritet, der legitimerer forskellige udsagn som særlig værdifuld viden. Bourdieu formulerer noget lignende i sin analyse af intellektuelle. Intellektuelle er personer, siger Bourdieu, som bruger de kompetencer, der er social anerkendte, til at komme med udsagn i offentligheden, som ligger uden for deres ekspertisefelt. (Bourdieu 1992: 29). Her skal man bemærke, at Bourdieu primært tænker på f.eks. forfattere eller andre kunstnere eller videnskabsfolk, som i kraft af deres renommé blander sig i det politiske liv og ikke på personer, der optræder som deciderede ekspertkilder i nyhedshistorier. Men også ekspertkilder tenderer at overskride deres ekspertiseområde. Den foreløbige konklusion bliver derfor, at den autoritet eller den vægt, som journalister efterspørger, konkret har form af særlige professioner, uddannelser og general social status og teoretisk kan anskues som forskellige former af kapital. Denne kapital anerkendes som symbolsk kapital, hvorved autoritet og kompetencer får en legitimitet, som Bourdieu stiller spørgsmålstegn ved. Bourdieu hævder i citatet foroven, at det ikke så meget er eksperternes konkrete viden eller kompetencer, men mere deres titler og grader, der gør dem til eksperter. Dette er naturligvis et meget polemisk udsagn, men dets pointe er, at eksperters viden og kompetencer og den status, som denne vidensbesiddelse medfører, er svære at skille ad. Og slutteligt handler det i høj grad også om, hvilke typer viden og hvilke kompetencer der anses for værdifulde og dermed kapitalgivende.

\section{Felter og nye ekspertprofessioner}

Foruden kulturel og økonomisk kapital findes der, som tidligere skrevet, en række andre kapitalformer. Disse forskellige typer af værdier skaber forskellige felter i samfundet. Felter skabes ved, at forskellige personer "kæmper" om den samme kapital (Bourdieu \& Wacquant 1996: 84-86). Felter er i praksis ofte meget lig med professionsgrupper. Bourdieu taler f.eks. om kunstens felt, journalistikkens felt, det akademiske eller videnskabelige felt og det økonomiske felt. I alle tilfælde konstitueres disse felter ved, at personer konkurrerer om nogle værdier, status eller i Bourdieus terminologi kapital. Det journalistiske felt rummer således en række personer, som alle forsøger at gøre karriere og dermed at positionere sig - i første gang over for hinanden, men også i samfundet generelt. Personerne i toppen af de respektive felter tenderer altså at udgøre samfundets „top“ eller „elite“ Magtudredningens analyse af den danske elite taler således om eliten inden for politik, forvaltning, domstole, organisationer, erhvervsliv, videnskab, medier og kultur (Christiansen 2001). Med undtagelse af organisationer udgør alle disse felter, som de er blevet analyseret af Bourdieu. 
På samme måde som personer inden for et givent felt ligger i en konstant indbyrdes konkurrence, foregår der også en stadig afstemning af forholdene mellem de forskellige felter. En høj position i ét felt kan således have en større værdi end en tilsvarende høj position i et andet. Af samme grund taler Bourdieu om, at der findes dominerende og dominerede felter. Disse hierarkier mellem felter varierer i takt med samfundsudviklingen. En af de udviklinger, som Bourdieu selv påpeger, er, at det akademiske felt og især de intellektuelles felt i de sidste godt tredive år har tabt i status - især i forhold til journalistikkens felt (Bourdieu 1992: 95), hvilket til gengæld er et felt, der har vundet status (Coenen-Huther 1998). Det, Bourdieu og flere Bourdieuinspirerede analyser påpeger, er med andre ord, at der er sket en forrykning i de hierarkier, der afgør, hvem der har magten til - i Bourdieus termer (Bourdieu 1988: 37; 1991: 166) - symbolsk at beskrive, definere eller konstruere virkeligheden (se også Frith \& Savage 1993). Her er massemedierne blevet vigtige, og dermed har journalistikkens felt vundet status i forhold til det akademiske og de intellektuelles felter.

Man kan udvide denne tese om nye magtfulde og statusgivende områder, hvor videns-, informations- og symbolarbejde foregår ved at inddrage teorier om ændringer i vidensproduktion. Her lægges der stor vægt på, at videns- og symbolarbejde i dag er dybt integreret i økonomi og produktion (Castells 2000; Gibbons, Limoges, Nowotny, Schwartzman, Scott \& Trow 1994; Nowotny 2000a), at forskning, udvikling og politisk tænkning i dag foregår i en række andre institutioner end den klassiske nemlig universitetet, der som konsekvens deraf mister status og betydning og befinder sig i en krisetilstand (Frith \& Savage 1993; Gibbons, Limoges, Nowotny, Schwartzman, Scott \& Trow 1994; Nowotny, Scott \& Gibbons 2001; Weaver 1989). Ydermere er viden og ekspertise i dag langt mere politiseret end tidligere. Flere politiske emner bliver diskuteret på baggrund af videnskab eller ekspertise samtidig med, at megen politisk debat og offentlighed i det hele taget foregår i, og er domineret af, massemedierne (Blumler \& Kavanagh 1999; Nowotny, Scott \& Gibbons 2001). Og endeligt, så rummer disse teorier en tese om, at viden og ekspertise er blevet relativiseret i den forstand, at der stilles spørgsmålstegn ved videnskabelig ekspertises legitimitet fra offentligheden og især mediernes side. Videnskabelig ekspertise har ikke længere nogen naturgiven legitimitet men må i stedet legitimere sig over for offentligheden. Denne udvikling forstærkes af pluraliseringen af vidensproduktion, idet der i dag findes en række nye vidensinstitutioner, der udgør alternativer til traditionel videnskabelig vidensproduktion og ekspertise. Disse nye vidensinstitutioner har dels vundet legitimitet, gennem en bedre evne til at markedsføre sig selv i offentligheden (læs medierne) end traditionelle vidensinstitutioner, dels er de bedre til at basere deres legitimitet på økonomiske rationaler.

Essensen af dette er, at legitimiteten af bestemte vidensformer for øjeblikket er "til forhandling," at en række nye aktører (vidensinstitutioner) byder 
ind, og at forhandlingen i høj grad foregår i offentligheden og dermed medierne. Hvis vi med ekspertise forstår videnssystemer med en særlig legitimitet, kan vi derfor tentativt argumentere, at ekspertise er blevet pluraliseret og til en vis grad relativiseret for så vidt, at den traditionelle videnskabelige ekspertise har mistet den legitimitet, den før havde mere eller mindre a priori. Dette betyder dog ikke, at offentligheden eller medierne er mindre afhængige af viden og ekspertise, eller at ekspertisens betydning relativeres - snarere tværtimod, ekspertise er på én og samme gang blevet mere vigtig og genstand for større usikkerhed og konfronteret med flere alternativer (Beck 1992; Beck, Bonss \& Lau 2003; Nowotny, Scott \& Gibbons 2001: se især 215-223). Dette gælder så absolut også medierne. Det kan godt være, at medierne stiller en række kritiske spørgsmål til traditionel videnskab, men der er samtidig ingen tvivl om, at mediernes selv i høj grad støtter sig til eksperter - jeg talte eksempelvis tidligere om "ffodfæste“. Viden og ekspertise bliver derfor ikke mindre vigtig. Snarere er der tale om, at viden og ekspertise i større grad udfordres af medierne og til en vis grad vinder sin legitimitet gennem medierne.

\section{Nye hierarkier}

Meget af dette kan ledes tilbage til Bourdieu. Til beskrivelsen af en ændret magtbalance mellem det akademiske og de intellektuelles felter på den ene side og journalistikkens felt på den anden side kan vi således tilføje, at også den traditionelle videnskabs tab af status til dels private forskningsinstitutioner og virksomheder, dels nye institutioner for social og politisk tænkning såsom tænketanke, betyder ændringer i hierarkierne mellem felterne samt opkomsten af en række nye former for vidensproduktion inden for økonomiens felt, der dermed får en række overlap med det akademiske og de intellektuelles og med journalistikkens felt. Denne ændring i balancen mellem felterne og den generelle diversificering af vidensproduktion i det moderne samfund betyder, at ekspertkilderne i nyhedshistorier i dag kan komme fra flere erhverv og flere felter sammenlignet med tidligere (Rich 2001). Ekspertkilden kan f.eks. være universitetsansat forsker, privatansat analytiker, ansat i privat tænketank, eller være redaktør eller journalist. Det, der synes at være fællestrækket, er, at disse erhvervsgrupper udfører symbolarbejde, der knyttes en relativ høj status til. For det andet betyder det, at en række af de eksperter, der bliver brugt, har tilhørsforhold til en række felter. Personer som Erik Meyer Carlsen, Ralf Pittelkow eller Henrik Dahl er alle eksempler på dette. Eksperter er altså personer, der i kraft af deres kapital - der er hentet fra en række forskellige felter besidder autoritet og dermed virker tillidsvækkende. Man kan mod dette indvende, at denne definition overser, at der findes forskellige typer eksperter, der bruges i forskellige sammenhænge, og at logikken i sammenhængen styres af reelle kompetencer. Der er således en forskel mellem den måde, som f.eks. Ralf Pittelkow og juraprofessor Peter Pagh benyttes på. Førstnævnte giver - baseret på sin konkrete erfaringer som politisk rådgiver og arbejde som 
politisk journalist - typisk mere brede vurderinger af det politiske spil, mens en juraprofessor leverer mere teknisk, juridisk information. Man kan endda endvidere begynde at inddele ekspertkilder i forskellige typer og for eksempel skelne mellem en „,kommentator" og en „ekspert.“ Sådanne kategoriseringer er til en vis grad mulige (Arnoldi 2005: kap. 6), men forskellene hviler først og fremmest på forskelle i kapital, og dermed forbliver fællestrækket netop kapital som noget autoritetsgivende, idet kapitalen gen- og anerkendes.

Som tidligere skrevet, er der er ingen tvivl om, at journalister i deres arbejde opererer med nogle meget komplekse scripts for, hvornår en given person har legitimitet som ekspert, og hvad der giver de givne personer legitimitet - scripts som i øvrigt deles med læsere, seere og lyttere. Dette inkluderer også nogle implicitte forståelser af, hvor objektive de forskellige eksperter kan (forventes at) være. Et eksempel kunne være følgende respondent, der diskuterer eksperttyper:

Man kan sige at eksperter falder i to afdelinger. Der er fageksperter; hvis vi brugte Tøger Seidenfaden som fagekspert på chefredaktørroller i Danmark ville han være fagekspert[...] Men vi bruger ham jo i vid udstrækning som kommentator [...]. Hvis man havde taget en økonom fra Københavns Universitet, så stiger de, altså jo mere fagpersoner de bliver, jo større bliver deres troværdighed i seernes og omverdenens øjne.

JA: Altså jo mere...?

Hvis det er en økonomisk vismand der går ud og siger noget, så tænker vi, jamen så står det jo standset i stålplader og bøjet i neon, at det er nok sådan er verden er, men det er jo ikke sandt.

JA: Men så mener du, at Tøger Seidenfaden ikke er fagperson?

Nej Seidenfaden er ekspert, men ikke så meget at det gør noget... Hvordan skal jeg forklare det? Han er ekspert, men som seere kender vi hans ståsted. Han er en meget vidende mand. Han er god til at tygge virkeligheden for os, det er tit det, vi bruger kommentatorer til; hvad-skal-vilægge-i-det-her-spørgsmålet. Men vi ved godt som seere, at det kommer an på, hvem man spørger.

JA: Jeg kan ikke lade være at tænke på alle de distinktioner, der bliver lagt, når man snakker om eksperter. Du har lavet en her, der handler om en skelnen mellem fageksperten og kommentatoren. Men det er jo en meget blød skelnen. Altså, man bliver jo nemt begge dele. I vil jo også gerne have eksperter, der er $i$ stand til at springe alle mellemregningerne over [...] og så bliver det vel kommenterende og mere baggrundsanalyserende?

Ja, det kommer an på, hvad det er. Og hvis alt skal være sandt, så er der jo altså meget forskel på, hvad de kommenterer på. Hvis de kommente- 
rer på hjemlige danske indenrigspolitiske forhold, så ender de meget nemt med at blive en part. Når jeg før sagde, at Seidenfaden er kommentator, mere end han er ekspert, så er der jo nogen ting, som de folk er eksperter i, nemlig magtstrukturer, altså de ved ualmindelig meget, også på et akademisk niveau, om magtstrukturer. Så på den måde kan man sige, at der får de en regulær ekspertrolle. Når det er magtstrukturer, de formidler, altså hvad sker der nu mellem regering og opposition, hvad er det for nogle linier, der er trukket op og sådan nogle ting, der er de eksperter (redaktionschef ved landsdækkende TV-station).

Interviewsekvensen viser samtidig, at disse forståelser af ekspertise stadig relaterer sig til kapital. Tøger Seidenfadens ekspertise i magtstrukturer - eller Ralf Pittelkows viden om politik - er således i vid udstrækning baseret på erfaring og journalistiske observationer og i mindre grad på teoretisk viden. Her vejer praktisk erfaring altså tungt. Men dette er en type praktisk erfaring, der stammer fra adgang til ellers ofte ekskluderende felter, der rummer megen status eller kapital. Således er der en modsætning mellem dette eksempel og f.eks. skolelærerens viden om unges kostvaner, hvilket var det hypotetiske eksempel, jeg indledte artiklen med. I modsætning til den imaginære skolelærer, er der her tale om personer, der er eller har været tæt på magten, og som selv har magt og status, Og kapitalen gen- og anerkendes af journalister såvel som af læsere, seere eller lyttere.

\section{Konklusion: Medieoptræden som kapital}

Bourdieu regner medieoptrædener for kapital, f.eks. inden for det akademiske felt. Det giver med andre ord status at optræde i medierne. På denne måde er medierne selv med til at skabe ekspertise. Kapital, og dette gælder især symbolsk kapital, er altid social; den hviler på gensidig gen- og anerkendelse af bestemte uddannelser og professioners autoritet. Eller som jeg skrev ovenfor, hviler brugen af ekspertise på en række scripts eller forforståelser af hvem, der har legitim ekspertise i hvilke sammenhænge. Disse forforståelser reproduceres eller „forhandles" løbende, også gennem mediernes udvælgelse af bestemte personer og professionsgrupper som ekspertise. Nyhedsmedierne udvælger altså ikke kun eksperter baseret på nogle i sidste ende sociale konventioner for, hvilke vidensformer og faggrupper der har en særlig legitimitet; deres udvælgelse er samtidig med til reproducere eller ændre disse videnshierarkier.

Hvor vigtig legitimering gennem medierne er, ses måske tydeligst i den måde den mest typiske form for "ny“ vidensinstitution - nemlig tænketanke forholder sig til medierne. Tænketanke - og især moderne typer af tænketanke - lægger stor vægt på og er generelt særdeles succesfulde med at få deres viden profileret i medierne (Arnoldi i tryk; Rich 2001). Tænketanke og andre nye vidensinstitutioner gør dette, dels fordi de derved får legitimeret den viden, de producerer, dels fordi de enten får solgt eller i det mindste skabt reklame for 
deres viden. Samtidig er tænketanke ofte de mest tydelige eksempler på politisk og strategisk vidensproduktion. Tænketanke er ofte sat i verden med politiske mål for øje og med det mål at påvirke offentligheden gennem målrettet PR-arbejde i forhold til medierne.

Man kan på denne baggrund spørge, hvad konsekvenserne af de nye eksperttypers opkomst vil være? Journalisters udvælgelse er med til at legitimere bestemte faggrupper som eksperter, samtidig med at spektrummet af mulige ekspertkilderer blevet udvidet i kraft af videnssamfundets udvikling. En del af denne udvikling har været en politisering af viden og ekspertise, hvor ekspertise bliver brugt strategisk i den massemedialiserede offentlighed - f.eks. gennem nye vidensinstitutioner såsom tænketanke. Det ville være naivt at hævde, at viden eller ekspertise på noget tidspunkt har været objektiv eller politisk neutral. Men der synes at være en klar tendens til en medieprofessionalisering af ekspertise, hvor især de nye vidensinstitutioner gennem målrettet pr-arbejde i forhold til journalister forsøger at påvirke dem, som er ganske ny. Journalister påvirkes i dag fra alle sider af pressemedarbejdere og andre, men i modsætning til en række andre typer kilder bruges eksperter ofte relativt ureflekteret. Set fra journalisternes side er ønsket at finde personer, der har den rette autoritet og legitimitet, men derudover er det relativt ligegyldig, hvem disse eksperter er. Og mens der ofte stilles kritiske spørgsmål til andre typer kilder, bliver ekspertkilder ofte brugt og især fremstilet på en ganske ukritisk måde. Dette skyldes ganske logisk, at mens der kan stilles spørgsmål til andre kilders udsagn, så er ekspertkildernes narrative rolle i nyhedshistorier at være den neutrale og objektive instans, der validerer og legitimerer. Denne rolle kan ikke forenes med kritiske journalistspørgsmål eller journalistisk brug af ekspertkilder, der stiller kildernes subjektivitet, partialitet eller interesser til skue. Journalisterne er således fanget i deres egne professionelle konventioner.

Jeg har i artiklen forsøgt at anskueliggøre, at "ekspertise" bedst begribes som symbolsk kapital. En sådan anti-essentialistisk tilgang til fænomenet ekspertise åbner op for en række videre overvejelser - f.eks. om,

1) hvordan samfundsforandringer også kan betyde ændringer af kapitalbesiddelser og åbninger af tidligere kapitalmonopoler, samt

2) hvordan forskellige kapitalformer omdannes til symbolsk kapital.

Disse videre overvejelser kan i en artikel af dette omfang kun antydes. Hvad angår det første punkt, har jeg forsøgt at anskueliggøre, at der er opstået en række ny "vidensprofessioner", der udfordrer de traditionelle monopolhavere på ekspertise, nemlig universitetsansatte forskere. Svaret på det andet spørgsmål er i langt højere grad kun antydet, men svaret er, at massemedierne i høj grad et det felt der i dag har den fornødne metakapital (Couldry 2003) til at omdanne feltspecifikke kapitalformer til symbolsk kapital, altså sikre den 
"misrecognition" som Bourdieu med kun en antydning af sarkasme taler om (se citat tidligere i artiklen). Udvælgelsen af ekspertkilder i massemedierne er altså langt fra noget ligegyldigt fænomen, men i stedet noget, der har store konsekvenser for, hvilken typer viden og hvilke professioner der anses for særlig gyldige. Massemedierne er et felt med megen kapital og indflydelse og derfor også et felt, der kræver nøje sociologisk undersøgelse Hvad vi ved, ved vi fra massemedierne, som Luhmann (2000: 1) siger. Det betyder også, hvilket jeg har argumenteret for her, at det er fra massemedierne, at vi ved, hvem der ved bedst.

\section{Noter}

1 Alle avisartikler i uge 46 i 2002 i de tre omnibusaviser Politiken, Jyllands-Posten og Berlingske Tidende, samt alle indslag i DR1's og TV2's hovednyhedsudsendelser (DR 18.30 og 21.00, TV2 19.00 og 22.00) i samme periode er gennemgået og alle historier, hvor ekspertkilder optræder, er udvalgt. „Ekspertkilder“ er her defineret ikke kun gennem profession men også gennem den rolle, som kilden spiller i nyhedshistorien. Det vil sige, at alle kilder, hvis udsagn tillægges vægt i historien og får lov at stå uimodsagt og hvor kilden generelt kan siges at være udvalgt i kraft af profession og professionel (teoretisk) viden er medtaget. Definitionen på ekspertkilde er altså ikke, at kilden er universitetsansat. Min ekspertdefinition er teoretisk og empirisk funderet, hvilket jeg håber bliver tydeligt i løbet af artiklen, men den har naturligvis også selv metodiske konsekvenser, idet den kan siges at være selvbekræftende: Mit argument er, at andre end kun universitetsforskere bruges som ekspertkilder, og jeg baserer dette på en empirisk undersøgelse af data, som er genereret gennem netop en bred definition af ekspertkilder, der inddrager andre end universitetsforskere.

\section{Litteratur}

Albæk, Erik, Christiansen, Peter Munk \& Togeby Lise 2002: Eksperter i medierne -

Dagspressens brug af forskere 1961-2001. Århus: Magtudredningen.

Arnoldi, Jakob 2005: Den Offentlige Ekspert . Frederiksberg: Samfundslitteratur.

Arnoldi, Jakob i tryk: „Informational Ideas“. Thesis Eleven,

Beck, Ulrich 1992: Risk Society - Towards a New Modernity. London: Sage.

Beck, Ulrich, Bonss, Wolfgang \& Lau, Christoph 2003: „The Theory of Reflexive Modernization“. Theory, Culture \& Society, 20, 2: 1-33.

Blumler, Jay G. \& Kavanagh, Dennis 1999: „The Third Age of Political Communication: Influences and Features". Political Communication, 16, 209-230.

Bourdieu, Pierre 1977: Outline of a Theory of Practice. Cambridge: Cambridge University Press.

Bourdieu, Pierre 1984: Distinction - a Social Critique of the Judgment of Taste. Cambridge: Harvard University Press.

Bourdieu, Pierre 1986: „The Forms of Capital“, i Richardson, John G. (red.): Handbook of Theory and Research for the Sociology of Education. New York: Greenwood Press.

Bourdieu, Pierre 1988: Homo Academicus. Cambridge: Polity Press.

Bourdieu, Pierre 1989: „,Social Space and Symbolic Power“. Sociological Theory, 7, 1:14-25.

Bourdieu, Pierre 1990: The Logic of Practice. Cambridge: Polity Press. 
Bourdieu, Pierre 1991: Language and Symbolic Power. Cambridge: Polity Press.

Bourdieu, Pierre 1992: Texter om de Intellektuella. Stockholm: Brutus Østlings Bokforlag.

Bourdieu, Pierre 1993: „Narzistiske Reflexivität und wissenschaftliche Reflexivität“, i Berg, Eberhard \& Fuchs, Martin (red.): Kultur, Soziale Praxis, Text. Frankfurt: Suhrkamp.

Bourdieu, Pierre 1997: Af Praktiske Grunde. Copenhagen: Hans Reitzels.

Bourdieu, Pierre \& Wacquant, Loïc J. D. 1996: Refleksiv Sociologi. Copenhagen: Hans Reitzels.

Castells, Manuel 2000: The Rise of the Network Society. Oxford: Blackwell.

Christiansen, Peter Munk 2001: Den danske elite. København: Hans Reitzels.

Coenen-Huther, Jacques 1998: „The Paths of Recognition: Bourdon, Bourdieu and the "Second Market" of Intellectuals". International Journal of Contemporary Sociology, 35, 2: 208-216.

Collins, H.M. \& Evans, Robert 2002: „The Third Wave of Science Studies: Studies of Expertise and Experience“. Social Studies of Science, 32, 2: 235-296.

Couldry, Nick 2003: „Media meta-capital: extending the range of Bourdieu's field theory". Theory and Society, 32, 653-677.

Frith, Simon \& Savage, Jon 1993: „Pearls and Swine: The Intellectuals and the Mass Media“. New Left Review, 198, 107-116.

Gibbons, Michael, Limoges, Camille, Nowotny, Helga, Schwartzman, Simon, Scott, Peter \& Trow, Martin 1994: The New Production of Knowledge. London: Sage.

Luhmann, Niklas 2000: The Reality of the Mass Media. Cambridge: Polity Press.

Nowotny, Helga 2000a: ,"The Production of Knowledge Beyond the Academy and the Market: A Reply to Dominique Pestre“. Science, Technology and Society, 5, 2: 183-194.

Nowotny, Helga 2000b: „Transgressive Competence“. European Journal of Social Theory, 3, 1: 5-21.

Nowotny, Helga, Scott, Peter \& Gibbons, Michael 2001: Re-Thinking Science - Knowledge and the Public in an Age of Uncertainty. Cambridge: Polity Press.

Potter, Jonathan 1996: Representing Reality. London: Sage.

Rich, Andrew 2001: „The Politics of Expertise in Congress and the News Media“. Social Science Quarterly, 82, 3: 583-601.

Steele, Janet E. 1995: „,Experts and the Operational Bias of Television News: The Case of the Persian Gulf War". Journalism and Mass Communication Quarterly, 72, 4: 799-812.

Weaver, R. Kent 1989: „The Changing World of Think Tanks“. Political Science and Politics, 22, 3: 563 - 578.

Wien, Charlotte 2001: „Journalisters brug af ekspertkilder i danske aviser“. Paper givet ved konferencen: 15th Nordmediakonferens, Reykavijk, 